\title{
PENGARUH FREKUENSI PEMBERIAN PAKAN PADA TINGKATAN UMUR TERHADAP SINTASAN LARVA BANDENG (Chanos chanos Forskal)
}

\author{
Agus Prijono*), Tony Setiadharma*) dan Titiek Aslianti*)
}

\begin{abstract}
ABSTRAK
Penelitian pemberian pakan yang didasarkan atas tingkatan umur larva bandeng di panti benih telah dilakukan. Tujuan penelitian adalah untuk mengetahui frekuensi pemberian pakan yang tepat pada tingkatan umur sehingga sintasan benih bandeng yang dihasilkan dapat ditingkatkan. Wadah penelitian berupa bak silinder serat gelas volume $1 \mathrm{~m}^{3}$ sebanyak 12 buah. Masing-masing wadah diisi air laut $600 \mathrm{~L}$ dan telur bandeng dengan kepadatan 30 butir/ L. Percobaan dilakukan dengan menggunakan rancangan acak lengkap yang terdiri atas 4 perlakuan frekuensi pemberian pakan dan masing-masing memiliki 3 ulangan. Selama pemeliharaan (23 hari) larva diberi pakan rotifer sesuai perlakuan yakni: (A) satu kali/hari, (B) dua kali/hari, (C) tiga kali per hari dan (D) satu kali pada umur 2-10 hari, dua kali pada umur 11-15 hari dan tiga kali pada umur 16-23 hari.

Hasil penelitian menunjukkan bahwa sintasan rata-rata tertinggi (42,53\%) diperoleh dari perlakuan A (satu kali/hari), yang secara nyata berbeda $(\mathrm{P}<0,05)$ dengan perlakuan $\mathrm{B}, \mathrm{C}$ dan $\mathrm{D}$ dengan sintasan berturut-turut $22.60,21,63$ dan $8,62 \%$.
\end{abstract}

\section{ABSTRACT: Effect of age-based feeding frequency on the survival rate of milkfish larvae (Chanos chanos Forskal). By:Agus Prijono,Tony Setiadharma and Titiek Aslianti.}

Experiment on age-based feeding frequency of milkfish larvae had been conducted. The objective of the experiment was to find out the best feeding frequency to improve survival rate of milkfish larvae. Twelve fibreglass tanks with volume of $1 \mathrm{~m}^{3}$ each filled with 600 liters of sea water were stocked with eggs at a density of 30 eggs/L. The experiments used completely randomized design where four types of treatments of feeding frequency were applied, i.e: oncel day (A), twice /day (B), three times /day (C), and one time at 2-10 DAH, 2 times at 11-15 DAH, 3 times at 16-23 DAH (D), each with three replications. The highest survival rate (42.53\%) was achieved by once/day feeding frequency (treatment $A)$, which was significantly different $(P<0.05)$ from other treatments.

KEYWORDS: feeding frequency, milkfish, survival rate.

\section{PENDAHULUAN}

Teknik pembenihan bandeng yang dirintis oleh Loka Penelitian Perikanan Pantai (Lolitkanta) Gondol sejak 1987 telah diadopsi oleh masyarakat sebagai usaha panti benih skala rumah tangga. Kendala yang dialami dalam usaha pembenihan tersebut adalah teknik penyediaan pakan alami, efisiensi penggunaan pakan, mutu dan cara pemberian pakan, sehingga larva yang dihasilkan mempunyai ukuran yang tidak seragam dan sintasan yang bervariasi. Hal tersebut disebabkan oleh beberapa faktor antara lain mutu pakan alami (rotifer), jumlah, serta cara pemberian rotifer yang tidak memadai. Penelitian-penelitian yang mengarah pada usaha perbaikan pemeliharaan seperti pemberian pakan alami (Aslianti et al., 1991), pengelolaan pakan, baik pakan alami dan buatan (Aslianti \& Azwar, 1992 dan Aslianti et al., 1993), dan cara pemberian pakan rotifer (Prijono et al., 1993) sudah dilakukan. Dalam pemeliharaan larva bandeng pada umur tertentu kebutuhan pakan sangat menonjol, terutama pada larva menjelang umur 10 hari dan makin meningkat pada larva menjelang umur 20 hari hingga panen (umur 23 hari). Larva pada umur tersebut sangat aktif mencari makan serta mempunyai gerakan yang sangat lincah. Di lain pihak Bagarinao (1991) berpendapat bahwa pertumbuhan larva bandeng dipengaruhi oleh faktor genetik dan lingkungan (antara lain: pakan, kompetisi, predator, suhu, salinitas, $\mathrm{DO}$ dan $\mathrm{pH}$ ), serta teknik manipulasi selama pemeliharaan seperti kepadatan dan frekuensi pemberian pakan. Penelitian tentang frekuensi pemberian pakan pada larva bandeng belum pernah dilaku-

\footnotetext{
*) Peneliti pada Loka Penelitian Perikanan Pantai Gondol
} 
kan dan hal tersebut sangat penting. Oleh karenanya perlu dilakukan penelitian untuk mengetahui pengaruh frekuensi pemberian pakan terhadap pertumbuhan dan sintasan larva bandeng. Dari penelitian tersebut diharapkan akan diperoleh cara pemberian pakan yang efektif sehingga dapat meningkatkan pertumbuhan dan sintasan larva.

\section{BAHAN DAN METODE}

Percobaan menggunakan dua belas bak serat gelas warna coklat berkapasitas 1000 L yang diisi air laut sebanyak $600 \mathrm{~L}$ dan dilengkapi dengan aerasi serta diletakkan pada ruang yang beratap serat gelas dengan tingkat kecerahan antara 7.500-15.000 lux pada siang hari. Telur dari hasil pemijahan yang sama ditebar pada masingmasing wadah dengan kepadatan rata-rata 30 butir/L. Selanjutnya larva yang menetas dipakai sebagai hewan uji.

Percobaan dilakukan dengan menggunakan rancangan acak lengkap yang terdiri atas empat perlakuan dan tiga ulangan. Perlakuan yang diuji adalah frekuensi pemberian pakan dalam pemeliharaan larva mulai umur 2 sampai umur 23 hari yaitu (A) pemberian pakan satu kali/hari, (B) dua kali/hari, (C) tiga kali per hari dan (D) satu kali pada larva umur 2-10 hari, dua kali pada larva umur 10-15 hari dan tiga kali per hari pada larva umur 16-23 hari. Untuk membedakan masing-masing perlakuan digunakan uji LSD dengan selang kepercayaan 95\%. Selama pemeliharaan larva diberi pakan berupa rotifer dari strain S dengan ukuran panjang lorica 180-240 mikron. Rotifer diperoleh dari pemeliharaan massal yang dikultur dengan menggunakan Nannochloropsis selama 4-5 hari, kemudian disaring dengan menggunakan plankton net ukuran 65 mikron. Selanjutnya hasil saringan rotifer tersebut ditingkatkan nutrisinya dengan cara merendam rotifer ke dalam air yang mengandung 6-7 juta sel/mL Nannochloropsis selama 2 jam dan selanjutnya diberikan pada larva sebagai pakan. Jumlah rotifer untuk pakan larva didasarkan pada tingkatan umur larva yakni, pada larva umur 2-5 hari kepadatan rotifer 3-5 ind./mL/hari, larva umur 6-10 hari kepadatan rotifer $10-15 \mathrm{ind} / \mathrm{mL} / \mathrm{hari}$, larva umur 11.15 hari kepadatan rotifer 20-25 ind./mL/hari dan larva umur 16.23 hari kepadatan rotifer $25-35$ ind. $/ \mathrm{mL} /$ hari. Nannochloropsis sebagai green water dan sebagai pakan rotifer diberikan pada larva mulai berumur 2 hari sampai 23 hari dengan kepadatan $10^{6} \mathrm{sel} / \mathrm{mL}$. Pergantian air dilakukan setiap tiga hari setelah larva berumur 10-16 hari sebanyak 20-30\% dan secara bertahap hingga pergantian air mencapai $100 \%$ pada saat menjelang panen (23 hari).

Pengamatan pertumbuhan larva yang dinyatakan dengan bobot dan panjang total dilakukan setiap lima hari masing-masing menggunakan alat jangka sorong berketelitian $0,01 \mathrm{~mm}$ dan timbangan analitik berketelitian 0,001 g. Pengamatan kualitas air sebagai data penunjang dilakukan setiap tiga hari meliputi oksigen terlarut, fosfat, nitrit $\left(\mathrm{NO}_{2} \mathrm{~N}\right)$, nitrat $\left(\mathrm{NO}_{3} \mathrm{~N}\right)$, suhu air dan salinitas.

\section{HASIL DAN BAHASAN}

Hasil pengamatan terhadap panjang total larva dari setiap perlakuan tidak menunjukkan perbedaan yang nyata $(P>0,05)$, sedangkan pertumbuhan bobot tubuh pada perlakuan $\mathrm{A}$ dan $\mathrm{B}$ berbeda nyata $(\mathrm{P}<0,05)$ dengan perlakuan $\mathrm{C}$ dan D (Tabel 1).

Pertumbuhan panjang yang cukup bagus diduga disebabkan oleh pemberian rotifer yang seimbang dengan kebutuhan larva yaitu sebanyak 10-15 ind./mL. Dengan jumlah pakan tersebut diperkirakan hampir seluruh larva memanfaat. kan rotifer. Hal ini terlihat dari hasil penga matan lambung secara mikroskopis yang menunjukkan bahwa rotifer yang dimakan berkisar antara 5-10 individu per hari. Kebutuhan larva untuk tumbuh antara lain dipengaruhi oleh kandungan nutrisi pakan yakni mengandung asam amino serta asam lemak. Tamaru et al. (1991) menyatakan bahwa rotifer mengandung asam amino dan asam lemak berturut-turut 40,96 mg dan 6,98 mg per $100 \mathrm{mg}$ bobot kering. Halver (1976) menyatakan pertumbuhan ikan umumnya sangat dipengaruhi oleh protein yang terkandung dalam pakan yang diberikan. Selain itu Cowey \& Robert (1985) dalam Widigdo (1989) juga menyampaikan bahwa komponen kimiawi pembentuk protein seperti asam amino pada protein dalam pakan alami lebih mudah dicerna sehingga metabolisme yang dihasilkan dapat memacu pertumbuhan larva. Diduga pertumbuhan yang menonjol sampai hari ke 10 pada perlakuan frekuensi pakan satu kali (A), karena larva mampu memanfaatkan rotifer sebagai pakan untuk pertumbuhan. Watanabe (1986) mengemukakan untuk mempertahankan hidup larva bandeng diperlukan $40 \%$ protein, sedangkan Hariati (1989) menyatakan bahwa secara umum larva ikan memerlukan pakan dengan kadar protein sebesar 50\%. Sebagai analogi dari pernyataan tersebut dapat dipastikan bahwa pengaruh kandungan protein rotifer sebesar 69,28\% sangat baik digunakan untuk pertumbuhan larva bandeng. Dari aspek per 
Tabel 1. Pengamatan pertumbuhan dan sintasan larva ikan bandeng yang dipelihara selama 23 hari.

Table 1. Observation on growth and survival rate of milkfish larvae for 23 days rearing.

\begin{tabular}{lccc}
\hline \multicolumn{1}{c}{$\begin{array}{c}\text { Perlakuan } \\
\text { Treatment }\end{array}$} & $\begin{array}{c}\text { Panjang total } \\
\text { Total length* } \\
\text { (mm) }\end{array}$ & $\begin{array}{c}\text { Bobot tubuh } \\
\text { Body weight* } \\
\text { (g) }\end{array}$ & $\begin{array}{c}\text { Sintasan } \\
\text { Survival rate* } \\
\text { (\%) }\end{array}$ \\
\hline A 1 kali/hari (1 time/day) & $12.58^{\mathrm{a}}$ & $0.035^{\mathrm{a}}$ & $42.53^{\mathrm{c}}$ \\
B 2 kali/hari (2 times/day) & $12.46^{\mathrm{a}}$ & $0.040^{\mathrm{a}}$ & $22.60^{\mathrm{b}}$ \\
C 3 kali/hari (3 times/day) & $12.66^{\mathrm{a}}$ & $0.050^{\mathrm{b}}$ & $21.63^{\mathrm{b}}$ \\
D 1 kali pada hari ke-2 sampai ke-10 (1 time on day 2-10) & $12.50^{\mathrm{a}}$ & $0.052^{\mathrm{b}}$ & $8.62^{\mathrm{a}^{\mathrm{b}}}$ \\
2 kali pada hari ke-11 sampai ke-15 (2 times on day 11-15) & & & \\
3 kali pada hari ke-16 sampai ke-23 (3 times on day 16-23) & & & \\
\hline
\end{tabular}

*) Nilai dalam kolom yang diikuti dengan huruf yang sama menunjukkan tidak berbeda nyata $(P>0,05)$. Values in the columns followed by similar letter are not significantly different $(P>0.05)$.

tumbuhan larva sampai akhir penelitian (umur 23 hari) tampak bahwa frekuensi pemberian pakan tiga kali memberikan bobot larva yang lebih tinggi walaupun panjang larva tidak berbeda. Hal ini karena pada perlakuan tersebut kepadatan rotifer dalam wadah konstan antara 25-35 ind./ $\mathrm{mL}$, berbeda dengan perlakuan lainnya yang hanya mencapai kepadatan rotifer antara 25-35 ind./mL. Hasil penelitian juga menunjukkan bahwa perlakuan frekuensi pakan berdasarkan tingkatan umur larva (perlakuan D) memberikan sintasan yang secara nyata jauh lebih rendah dari perlakuan-perlakuan lainnya (Tabel 1). Meningkatnya jumlah rotifer dalam bak larva akan menjamin kualitas larva dan rotifer tetap baik (Tabel 2).

Hasil pengamatan terhadap larva pada setiap wadah pemeliharaan menunjukkan bahwa larva yang diberi pakan dengan frekuensi $1 \mathrm{kali} / \mathrm{hari}$ mempunyai gerak renang yang sangat aktif menyerang pakan dan pada pengamatan secara mikroskopis terhadap isi lambung larva, menunjukkan bahwa setiap larva memakan rotifer sebanyak 5-15 ind., sedangkan pada sore hari melalui mikroskop diketahui bahwa pada lambung larva ditemukan rotifer tersisa sebanyak 2-5 ind. Pada perlakuan frekuensi pemberian pakan 2 dan $3 \mathrm{kali} / \mathrm{hari}$, larva menunjukkan gejala

Tabel 2. Pengamatan kualitas air selama percobaan.

Table 2. Observation of water quality during experiment.

\begin{tabular}{lcccc}
\hline \multirow{2}{*}{$\begin{array}{c}\text { Parameter } \\
\text { Parameters }\end{array}$} & \multicolumn{4}{c}{ Perlakuan (treatment) } \\
\cline { 2 - 5 } & A & B & C & D \\
\hline Suhu (Temperature) $\left({ }^{0} \mathrm{C}\right)$ & $26.2-27.9$ & $26.2-27.5$ & $26.3-28.2$ & $26.2-28.2$ \\
Salinitas (Salinity) (ppt) & $34-35$ & $34-35$ & $34-35$ & $34-35$ \\
pH & $8.0-8.57$ & $8.11-8.61$ & $8.10-8.63$ & $8.12-8.87$ \\
Oksigen (Oxygen) (mg/L) & $6.40-7.62$ & $6.37-7.77$ & $6.51-7.60$ & $6.57-7.77$ \\
Fosfat (Phosphate) (mg/L) & $0.043-0.175$ & $0.039-0.172$ & $0.050-0.153$ & $0.070-0.165$ \\
Nitrit (Nitrite) $(\mathrm{mg} / \mathrm{L})$ & $0.063-1.429$ & $0.069-1.429$ & $0.071-1.919$ & $0.060-1.900$ \\
Nitrat (Nitrate) $(\mathrm{mg} / \mathrm{L})$ & $0.220-2.377$ & $0.130-2.205$ & $0.490-2.351$ & $0.240-2.258$ \\
\hline
\end{tabular}

Catatan (Remarks):

$\mathrm{A}=$ satu kali pemberian pakan per hari (1 time feeding/day);

$\mathrm{B}=$ dua kali pemberian pakan per hari (2 times feeding/day);

$\mathrm{C}$ = tiga kali pemberian pakan per hari (3 times feeding/day);

$\mathrm{D}$ = satu kali pemberian pakan pada hari ke-2 sampai ke-10 (1 time at day 2-10), dua kali pemberian pakan pada hari ke-11 sampai ke-15 (2 times at day 11-15), tiga kali pemberian pakan pada hari ke-16 sampai ke-22 (3 times at day 16-22) 
kekurangan pakan. Hal tersebut dapat diketahui dari hasil pengamatan secara mikroskopis isi lambung yang ternyata hanya ditemui rotifer antara 0-5 ind./larva. Hal yang sama terjadi pada perlakuan frekuensi pemberian pakan yang didasarkan umur larva (perlakuan D). Berdasarkan pengamatan isi lambung tampak bahwa larva yang hidup mempunyai keragaan yang baik karena larva yang tidak memperoleh pakan cukup akan menjadi lemah dan mati sedangkan yang cukup memperoleh pakan akan bertahan hidup, sehingga sejumlah pakan yang diberikan hanya dimanfaatkan oleh larva yang hidup saja. Dengan demikian larva pada perlakuan B,C dan D memperlihatkan pertumbuhan yang sangat baik namun tingkat sintasannya rendah yaitu berturut-turut hanya mencapai 22,60; 21,63 dan $8,62 \%$.

Menurut Effendie (1979), pertumbuhan ikan dapat dipengaruhi oleh beberapa faktor di antaranya adalah kualitas air, pakan dan sifat biologis ikan. Prijono et al. (1986) mengemukakan bahwa larva bandeng dapat hidup baik pada suhu $26-30,5^{\circ} \mathrm{C}$, sedangkan menurut Liao et al. (1979) kisaran suhu optimum untuk larva bandeng antara $27-29,5^{\circ} \mathrm{C}$. Dari pengamatan mutu air selama penelitian ternyata seluruh parameter masih berada dalam batas yang normal bagi kehidupan larva bandeng (Tabel 2).

\section{KESIMPULAN}

Frekuensi pemberian pakan satu kali/hari menghasilkan sintasan larva bandeng tertinggi $(42,53 \%)$ dan berbeda nyata $(\mathrm{P}<0,05 \%)$ dengan perlakuan yang lain walaupun dari nilai pertumbuhan panjang tidak berbeda nyata dan bobot tubuh berbeda.

\section{UCAPAN TERIMA KASIH}

Terima kasih disampaikan kepada teknisi litkayasa Sdr. I G. Putu Oka Suarjana, Made Suparya, Dedi Rohaniawan, Agus Supriyatna serta teknisi kimia Sdri Ayu Kenak, Ari Arsini dan Darsudi yang telah banyak membantu dalam pelaksanaan penelitian hingga selesai.

\section{DAFTAR PUSTAKA}

Aslianti,T., Prijono, A. dan Irianti, S.N. 1991. Pengaruh pemberian pakan alami yang berbeda terhadap tingkat kelangsungan hidup larva bandeng (Chanos chanos F.). Laporan Penelitian. Sub Balitkandita Gondol, Bali. 8 pp.

Aslianti,T, dan Azwar, Z.I. 1992. Kombinasi makanan alami dan makanan buatan pada pemeliharaan larva bandeng. J. Penelitian Budidaya Pantai 8(4): 1-8.

Aslianti,T., Prijono, A. dan Ahmad, T. 1993. Pengaruh pemberian pakan alami dan pakan buatan terhadap kelangsungan hidup larva bandeng Chanos chanos Forsskal. J. Penelitian Budidaya Pantai 9(1): 81 . 89.

Bagarinao, T.U. 1991. Biology of Milkfish (Chanos chanos Forskal). Aquaculture Deparment Southeast Asian Fisheries Development Centre Tigbauan. Iloilo, Philippines. 99 p.

Effendie. 1979. Biologi Perikanan. bag. I. Study natural history. Fakultas Perikanan. IPB Bogor. 105 pp.

Halver, J.E. 1976. Fish Nutrition. Academic Press London and New York. 713 pp.

Hariati, A.M. 1989. Makanan Ikan. NUFFIC/ UNIBRAW/LUW/FISH. Fisheries Project, Malang. $155 \mathrm{pp}$.

Liao, I.C., Juario, J.V., Kumagai, S., Nakajima, H., Natividad. M. and Buri, P. 1979. On the induced spawning and larval rearing of milkfish, (Chanos chanos Forskal). Aquaculture 18: 75-93.

Prijono, A., Tridjoko dan Giri, I.N.A. 1986. Pengamatan perkembangan telur dan larva ikan bandeng Chanos chanos Forsskal. J. Penelitian Budidaya Pantai. 2: 1-12.

Prijono, A., Aslianti, T. dan Rohaniawan, D. 1993. Pengaruh waktu pemberian rotifer terhadap kelangsungan hidup larva bandeng Chanos chanos Forsskal. J. Penelitian Budidaya Pantai 9 (3): 67 71.

Tamaru, C.S.. Lee, C.S. and Ako, H. 1991. Improving the larval rearing of striped mullet (Mugil cephalus) by manipulating quantity and quality of the rotifer, Brachionus plicatilis. In: Fulks, W. and Main (Eds.) Rotifer and microalgae culture system. Proc. of a U.S. Asia Workshop. The Oceanic Intitute, Honolulu, H.I. U.S.A. 89-103.

Watanabe, W.O. 1986. Larva and larva culture. In Lee C.S., Gordon, M.S. and Watanabe, W.O. (Eds), Aquaculture of milkfish (Chanos chanos F): State of the art. The Oceanic Institute. Hawaii. U.S.A. $117-142$.

Widigdo,B. 1989. Evaluasi histologis pemanfaatan Brachionus caliciforus (Rotifer) sebagai pakan awal larva ikan dan metoda kultur massal. Dalam Ilyas, S., Cholik, F., Heruwati, E.S., Suparno, Kompyang, I.P., Rabegnator, I.N. dan Murtini, J.T. (Eds.). Prosiding Temu Karya Ilmiah Penelitian Menuju Program Swasembada Pakan Ikan Budidaya, Jakarta 30-31 Agustus 1989. Pusat Penelitian dan Pengembangan Perikanan Jakarta. 53-61. 